\title{
Influence of irrigation mode on winter wheat production and moisture changes of wheat fields under extreme rainfall patterns
}

\author{
Xiaoshuang Li ${ }^{1,3}, \mathrm{Ni}$ Song $^{1}$, Xiaojun Shen ${ }^{1}$, Jingsheng Sun ${ }^{1, *}$, and Hongkai Dang,, \\ ${ }^{1}$ Farmland Irrigation Research Institute, Chinese Academy of Agricultural Sciences, Xinxiang, China \\ ${ }^{2}$ Dryland Farming Institute, Hebei Acadamy of Agricultural and Forestry Sciences, Hengshui, China \\ ${ }^{3}$ Graduate school of Chinese academy of agricultural sciences
}

\begin{abstract}
This work studied the effect of irrigation measures on water changes and crop growth in wheat fields during extreme drought years with rainfall of only $47.7 \mathrm{~mm}$ during the wheat growth period. Field investigation was carried out in the low plains of Hebei Province. In the experiment, six water-saving wheat varieties were used, and five irrigation levels $(0 \mathrm{~mm}, 75 \mathrm{~mm}, 150 \mathrm{~mm}, 225 \mathrm{~mm}$ and $300 \mathrm{~mm}$ designated as $\mathrm{T} 0, \mathrm{~T} 1, \mathrm{~T} 2, \mathrm{~T} 3$ and T4, respectively) were set in the spring. Results showed that wheat yield ranged from $70.5 \mathrm{~kg} / \mathrm{hm} 2$ to $7053.0 \mathrm{~kg} / \mathrm{hm} 2$. With the increase in irrigation times, yield level gradually increased and was highest under the $\mathrm{T} 4$ treatment. The effect of irrigation mode on panicle number was different from that on yield. The T0 treatment group had the smallest panicle number, whereas the other treatment groups showed slight differences and no discernible trend. The range of 1000-grain weight of different varieties of wheat was 33.36-46.68 g. Except for the T0 treatment, all other treatments increased with the increase in irrigation times. The difference between panicle and grain number was irregular and related to varieties. When population difference was large, yield was related to population size. When the population difference was small, yield was correlated with 1000-grain weight. From the perspective of soil water changes, in the late growth stage, the water content of deep soil under T0 and T4 treatments was higher, whereas that under $\mathrm{T} 1$ and $\mathrm{T} 2$ treatments was lower. This result indicated that $\mathrm{T} 1$ and $\mathrm{T} 2$ irrigation modes were conducive for the full utilisation of water in deep soil and were efficient water use modes. T1 and T2 were water saving irrigation models in this study. These conclusions can provide a theoretical basis for guiding the selection of irrigation patterns for wheat cultivation during spring.
\end{abstract}

\section{Introduction}

Hebei Province is a major grain-producing area in China. Its main grain crop is winter wheat. In this region, the annual sown area is 35 million $\mathrm{mu}$, the output is 14.3 million tonnes, and the net transfer amount is 4.9 million tonnes. Thus, Hebei Province provides an important contribution to ensuring national food security. At the same time, Hebei Province has insufficient water resources. The average annual rainfall during the wheat growing period is $109 \mathrm{~mm}$, which could only meet $1 / 4$ of the water requirement [1]. For many years, meteorological drought has occurred frequently in this region during winter and spring, especially during the wheat jointing stage [2]. High and stable wheat yields require highfrequency irrigation to maintain. The annual irrigation water requirement of wheat is approximately 7 billion $\mathrm{m} 3$ in the whole province, accounting for half of the annual agricultural water consumption. Wheat is a crop with the highest irrigation water requirement. Given the lack of surface water, groundwater has been overexploited year after year, and groundwater levels have decreased by 1-1.7 m per year. These phenomena have caused serious ecological and environmental problems. In 2014, the government launched a pilot project for the comprehensive treatment of groundwater overextraction in Hebei Province, and appropriate water-saving technologies need to be developed. Establishing a reasonable irrigation system model and utilising water resources efficiently are crucial for sustainable agricultural development.

Considerable research has been conducted on the effects of spring irrigation on winter wheat growth, water use and yield formation. Li et al. [3] pointed out that water use efficiency could be improved if spring water irrigation meets the requirement of yield formation. Li et al. [4] and Wang et al. [5] believed that appropriately delaying jointing water for 515 days could significantly improve grain yield, water use efficiency and irrigation efficiency. Differences in water

* Corresponding author: jshsun623@,163.com; wheatcrop@,126.com 
sensitivity, drought resistance and water-saving capacity are related to varieties [6]. Reasonable irrigation helps improve the growth and development of plants and regulate population [7]. Different areas have different ecological conditions and appropriate irrigation modes. Aswp water + spring 1 water mode is suitable for the western hilly area of Anyang [8], and aswp water + jointing water and aswp water + jointing water + flowering water modes are suitable for Ludong Peninsula [9]. The present study adopted a split area design with different irrigation times and irrigation amounts during spring as the main treatment and six local winter wheat varieties as the secondary treatment under the extreme drought condition of $47.7 \mathrm{~mm}$ precipitation during the wheat growing season. The effects of different irrigation times and irrigation amount on wheat growth yield and water utilisation were analysed to provide data support for a rational irrigation system and water-efficient planting model in this area.

\section{Materials and methods}

\subsection{Basic test information}

The field experiment was conducted at the Experimental Station for Water Saving in Dry Farming $\left(115.72^{\circ} \mathrm{E}, 37.90^{\circ} \mathrm{N}\right.$, altitude $21.0 \mathrm{~m}$ ) of the Hebei Academy of Agricultural and Forestry Sciences. The station is located in the central and southern part of the Hebei Plain. It is part of the wheat-growing area of north China and has the typical characteristics of a semiarid agricultural production area in north China. Winter wheat and summer corn are used for double cropping in a year. Average annual sunshine duration, frost-free period, evaporation, precipitation and temperature are $2509.4 \mathrm{~h}, 188$ days, $1785 \mathrm{~mm}, 510 \mathrm{~mm}$ and $12.8{ }^{\circ} \mathrm{C}$, respectively [4]. The soil in the test field is loam, and the soil nutrient composition in the $0-20 \mathrm{~cm}$ topsoil is as follows: $15.68-17.42 \mathrm{~g} / \mathrm{kg}$ organic matter, $1.48-1.54 \mathrm{~g} / \mathrm{kg}$ total nitrogen, $127.24-134.68$ $\mathrm{mg} / \mathrm{kg}$ available nitrogen, $21.95-24.13 \mathrm{mg} / \mathrm{kg}$ available phosphorus and $113.68-128.42 \mathrm{mg} / \mathrm{kg}$ available potassium. The rainfall year is an extremely dry year with $47.7 \mathrm{~mm}$ of rainfall during the whole wheat growing season; this value is far lower than the average rainfall $(109 \mathrm{~mm})$. The distribution of rainfall during the winter wheat growing season is as follows: no effective rainfall for 107 days from October 25 to February 8, followed by $5.0 \mathrm{~mm}$ of rainfall in February, 0 $\mathrm{mm}$ of rainfall in March, $8.6 \mathrm{~mm}$ of rainfall in April and $34.1 \mathrm{~mm}$ of rainfall from May to wheat harvest.

\subsection{Test design}

The experimental field adopted a split area design and sufficient soil moisture sowing. The main treatment was different spring watering times, and the secondary treatment was different wheat varieties. The water treatment was divided into five levels in accordance with the number of spring watering: 0 water, 1 water, 2 water, 3 water and 4 water designated as T0, T1, T2, T3 and T4, respectively. Each irrigation was $45 \mathrm{~m}^{2} / \mathrm{mu}$. Six subtreated wheat varieties were applied: Hengguan 35, Shi 4185, Shimai 15, Heng 4399, Guan 216 and Jimai 22. The sowing time was on October 16 of the same year (under sufficient soil moisture). The sowing amount was $210 \mathrm{~kg} / \mathrm{hm}^{2}$. The base fertiliser amount was diammonium $225 \mathrm{~kg} / \mathrm{hm}^{2}\left(\mathrm{P}_{2} \mathrm{O}_{5} 46-\mathrm{N} 18\right)+$ urea $150 \mathrm{~kg} / \mathrm{hm}^{2}(\mathrm{~N} 46)$ and diammonium $247.5 \mathrm{~kg} / \mathrm{hm}^{2}\left(\mathrm{P}_{2} \mathrm{O}_{5} 46-\mathrm{N} 18\right)+\mathrm{urea} 150 \mathrm{~kg} / \mathrm{hm}{ }^{2}$ (N 46). The amount of urea applied in spring was $375 \mathrm{~kg} / \mathrm{hm}^{2}$ combined with the first water in spring. The harvest was on June 9 of the following year.

Table 1. Spring winter wheat irrigation schedule.

\begin{tabular}{cccccc}
\hline \multirow{2}{*}{$\begin{array}{c}\text { Irrigation } \\
\text { mode }\end{array}$} & $\begin{array}{c}\text { Irrigation } \\
\text { amount }\end{array}$ & \multicolumn{5}{c}{ Irrigation time } \\
\cline { 3 - 6 } T0 & 0 & & 2 & 3 & 4 \\
T1 & 75 & April 15 & & & \\
T2 & 150 & April 10 & May 7 & & \\
T3 & 225 & March 25 & April 25 & May 21 & \\
T4 & 300 & March 20 & April 10 & May 2 & May 21 \\
\hline
\end{tabular}

\subsection{Soil moisture survey}

During the key growth period of wheat, soil samples from the 0-200 cm soil layer were collected by using a soil drill in each $10 \mathrm{~cm}$ layer. Soil was taken from each side three times. Soil moisture content was determined through the drying method.

\subsection{Field investigation of plant characteristics}

\subsubsection{Plant trait}


In each treatment, 30 seedlings were taken as investigation samples. Plant height and leaf area were investigated plant by plant. After investigating the traits of a single plant, the roots were removed, and the plant was placed in an oven at $105{ }^{\circ} \mathrm{C}$ for degreening and dried at $80^{\circ} \mathrm{C}$ to a constant weight. After cooling, the dry weight of single plant was weighed and calculated.

\subsubsection{Leaf area index (LAI)}

In the sampling, three representative plants were selected as sample plants, the lengths and widths of all leaves were measured. Three green leaves (sample leaves) were dried and weighed separately, and LAI was calculated in accordance with the following formula:

LAI $=\left[\right.$ the sample leaf area $\left(\mathrm{cm}^{2}\right) \div$ the sample leaf weight $\left.(\mathrm{g})\right] \times$ total green leaf weight of sample $(\mathrm{g}) \div$ the sample number $\times$ the basic seedling $\left(\right.$ plant $\left.\cdot \mathrm{m}^{2}\right) \times 10^{4}$

\subsubsection{Determination of yield and yield components}

The panicle number at various points in the field was counted before maturity, and the panicle number per hectare was calculated. Then, 20 panicles were randomly collected from the sample points to investigate the panicle grain number. Approximately 30 plants were collected from the same plot of land, and plant characteristics were investigated individually. Three sample points of $2 \mathrm{~m}^{2}$ were harvested in each district, and the yield was converted into hectares. Seeds dried at various points were randomly selected and weighed in the thousands.

\subsection{Data processing method}

Excel and SPSS software were used for data processing and statistical analysis.

\section{Results and analysis}

\subsection{Effects of different irrigation modes on the dynamic changes of soil moisture in the $0-200 \mathrm{~cm}$ soil layer}

Irrigation is the main factor that affected soil water content because rainfall was limited during wheat growth during this year. As seen from Figure 1, the water content of each soil layer followed a common trend because the irrigation treatment was not implemented during and before the period of rejuvenation. All treatments had high water contents in the $0-40$ and 40-60 cm soil layers and negligible difference in water content in soil layers below $80 \mathrm{~cm}$. After irrigation (T4 treatment) in the regreening stage, the difference began to appear in the jointing period, and the water content in the 40-80 cm soil layer was significantly higher than that in the irrigated plot. In each growth period, T4 had the highest or higher soil water content amongst all treatments. However, the water content of subsoil under T0 treatment was not the lowest at the late growth stage. This result may be related to the low-water T0 treatment of wheat seedlings. However, the water content of the subsoil under T0 treatment was not the lowest at the late growth stage likely because of the low number of T0 wheat seedlings and the low utilisation of deep water.
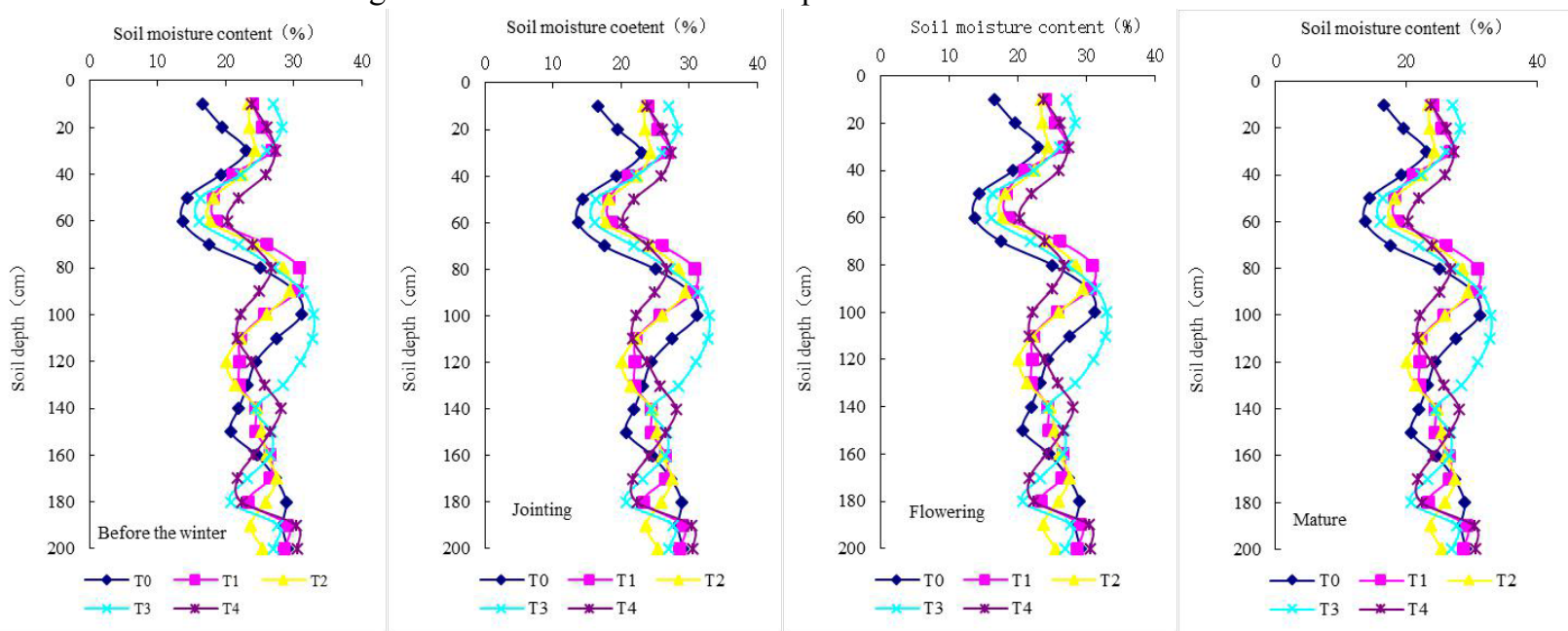

Fig. 1. Soil moisture content of the $0-200 \mathrm{~cm}$ soil layer at different periods. 


\subsection{Effects of water management on individual growth and the development of wheat groups}

\subsubsection{Dynamic changes in the total stem number of leaves and population of wheat in different periods}

As seen from Table 2, the leaf area of individual plants in each treatment negligibly differed at the rising stage, and the leaf area of individual plants under T0 treatment after the rising stage was close to 0 . The area of leaves of T1, T2, T3 and T4 varied across different varieties at the jointing stage. The leaf areas of individual plants of Jimai 22, Shimai 15 and Shimai 4185 were the largest under T1 treatment. The leaf areas of individual plants of Guan216 and Heng 4399 were highest or higher under T4 treatment. The leaf areas of individual Hengguan 35 plants did not significantly differ between treatments. Amongst all treatments, T4 treatment was the highest or higher in the flowering and filling stage, and T1 treatment was the lowest or lower.

Table 2. Leaf area and total stem number of a single plant at different growth stages under different treatments.

\begin{tabular}{|c|c|c|c|c|c|c|c|c|c|}
\hline \multirow[b]{2}{*}{ Varieties } & & \multicolumn{4}{|c|}{ Leaf area per plant $\left(\mathrm{cm}^{2} /\right.$ plant $)$} & \multicolumn{4}{|c|}{ The total stem number $\left(10^{4} \mathrm{plant} / \mathrm{hm}^{2}\right)$} \\
\hline & & $\begin{array}{c}\text { Standing } \\
\text { stage }\end{array}$ & $\begin{array}{c}\begin{array}{c}\text { Jointing } \\
\text { stage }\end{array} \\
\end{array}$ & $\begin{array}{c}\text { Flowing } \\
\text { stage }\end{array}$ & $\begin{array}{c}\text { Filling } \\
\text { stage }\end{array}$ & Basic seedlings & Before Winter & The highest & Mature stage \\
\hline \multirow{5}{*}{ Hengguan 35} & T0 & 15.6 & - & - & - & 481.67 & 1734.0 & - & - \\
\hline & $\mathrm{T} 1$ & 20.7 & 77.9 & 35.2 & 32.8 & 468.33 & 1358.8 & 1900.6 & 434.91 \\
\hline & $\mathrm{T} 2$ & 18.3 & 77.9 & 40.9 & 31.4 & 488.33 & 1917.8 & 1979.2 & 410.37 \\
\hline & $\mathrm{T} 3$ & 17.4 & 79.4 & 44.9 & 36.2 & 475.00 & 1377.5 & 1844.5 & 445.93 \\
\hline & $\mathrm{T} 4$ & 20.7 & 81.2 & 50.8 & 42.1 & 456.67 & 1552.7 & 1987.1 & 470.00 \\
\hline \multirow{5}{*}{ Shimai4185 } & T0 & 9.6 & - & - & - & 531.67 & 1530.7 & - & - \\
\hline & $\mathrm{T} 1$ & 4.8 & 68.0 & 33.5 & 14.3 & 531.67 & 1640.0 & 1968.0 & 508.15 \\
\hline & $\mathrm{T} 2$ & 4.2 & 63.2 & 28.6 & 20.5 & 523.33 & 2093.3 & 1290.9 & 510.74 \\
\hline & $\mathrm{T} 3$ & 12.8 & 56.3 & 27.3 & 20.5 & 524.40 & 1938.0 & 1598.0 & 487.41 \\
\hline & $\mathrm{T} 4$ & 9.6 & 49.0 & 33.4 & 25.9 & 530.00 & 2067.0 & 1431.0 & 538.15 \\
\hline \multirow{5}{*}{ Heng4399 } & T0 & - & - & - & - & 493.33 & 1480.0 & - & - \\
\hline & $\mathrm{T} 1$ & 14.3 & 62.2 & 31.6 & 20.0 & 475.00 & 1333.0 & 1476.3 & 462.96 \\
\hline & $\mathrm{T} 2$ & 16.4 & 59.8 & 29.3 & 27.6 & 482.10 & 1530.0 & 1938.0 & 504.81 \\
\hline & $\mathrm{T} 3$ & 17.9 & 61.2 & 32.7 & 22.8 & 453.33 & 1269.3 & 1813.3 & 494.44 \\
\hline & $\mathrm{T} 4$ & 14.9 & 68.1 & 38.1 & 32.3 & 456.67 & 1370.0 & 1796.2 & 573.33 \\
\hline \multirow{5}{*}{ Guan216 } & T0 & - & - & - & - & 485.00 & 1649.0 & - & - \\
\hline & $\mathrm{T} 1$ & 18.9 & 48.9 & 26.6 & 15.9 & 506.67 & 1875.7 & 2151.5 & 497.61 \\
\hline & $\mathrm{T} 2$ & 20.7 & 44.0 & 30.6 & 21.8 & 469.20 & 1627.5 & 1907.5 & 541.11 \\
\hline & $\mathrm{T} 3$ & 14.8 & 60.6 & 30.6 & 21.9 & 476.67 & 1573.0 & 2017.9 & 506.81 \\
\hline & $\mathrm{T} 4$ & 20.8 & 59.3 & 35.8 & 28.1 & 475.35 & 1488.0 & 1844.5 & 558.50 \\
\hline \multirow{5}{*}{ Shimai15 } & T0 & 14.2 & - & - & - & 481.67 & 1734.0 & - & - \\
\hline & $\mathrm{T} 1$ & 18.8 & 82.4 & 29.5 & 15.9 & 468.33 & 1358.8 & 1900.6 & 455.74 \\
\hline & $\mathrm{T} 2$ & 16.4 & 67.0 & 35.0 & 25.7 & 458.33 & 1917.8 & 1979.2 & 493.33 \\
\hline & $\mathrm{T} 3$ & 14.4 & 71.4 & 29.5 & 20.8 & 475.00 & 1377.5 & 1844.5 & 509.04 \\
\hline & $\mathrm{T} 4$ & 14.2 & 79.1 & 40.4 & 29.5 & 456.67 & 1552.7 & 1987.1 & 589.44 \\
\hline \multirow{5}{*}{ Jimai22 } & T0 & 13.8 & & & & 478.33 & 1390.0 & - & - \\
\hline & $\mathrm{T} 1$ & 14.7 & 93.5 & 43.1 & 17.4 & 483.33 & 1305.0 & 1910.2 & 548.89 \\
\hline & $\mathrm{T} 2$ & 14.6 & 74.5 & 36.7 & 26.3 & 481.67 & 1842.0 & 1852.8 & 567.69 \\
\hline & $\mathrm{T} 3$ & 17.4 & 71.7 & 31.4 & 23.7 & 483.33 & 1401.7 & 1811.4 & 523.33 \\
\hline & $\mathrm{T} 4$ & 14.8 & 79.7 & 39.5 & 25.4 & 475.00 & 1425.0 & 1997.8 & 606.89 \\
\hline
\end{tabular}

As can be seen from Table 2, the numbers of wheat seedlings and total stems were basically the same as those before winter because irrigation had not been implemented before and during early winter. The total number of stems under T0 was low after the regreening period because of the following reasons: Firstly, the weather was too dry. Secondly, the sowing depth for this year was deep, and the seedlings before winter were weak. After the returning green period, negligible difference was observed amongst different varieties under different water treatments.

\subsubsection{Dynamic changes in dry matter accumulation in wheat at different periods}


Dry matter accumulation under the T0 treatment was the lowest or low during the rise period, and that under the T0 treatment tended to be 0 after the rise period. This trend was basically consistent with the trend shown by the change in leaf area per plant. The difference in dry matter accumulation during the jointing stage under T1, T2, T3 and T4 treatments was not obvious. Dry matter accumulation under T3 and T4 treatment was the highest during the flowering stage, whereas that under T1 and T2 was low. Dry matter accumulation during the maturity stage was highest under T4 followed by T3, T2 and T1.

Table 3. Dynamic change in dry matter accumulation.

\begin{tabular}{|c|c|c|c|c|c|c|c|c|c|c|}
\hline \multirow[b]{2}{*}{ Variety } & \multirow[b]{2}{*}{ Treatment } & \multicolumn{4}{|c|}{ Growth stage } & \multirow[b]{2}{*}{ Variety } & \multicolumn{4}{|c|}{ Growth stage } \\
\hline & & $\begin{array}{c}\text { Standing } \\
\text { stage }\end{array}$ & $\begin{array}{c}\text { Jointing } \\
\text { stage }\end{array}$ & $\begin{array}{c}\begin{array}{c}\text { Flowing } \\
\text { stage }\end{array} \\
\end{array}$ & $\begin{array}{c}\text { Filling } \\
\text { stage }\end{array}$ & & $\begin{array}{c}\text { Standing } \\
\text { stage }\end{array}$ & $\begin{array}{c}\begin{array}{c}\text { Jointing } \\
\text { stage }\end{array} \\
\end{array}$ & $\begin{array}{c}\begin{array}{c}\text { Flowing } \\
\text { stage }\end{array} \\
\end{array}$ & $\begin{array}{c}\text { Filling } \\
\text { stage }\end{array}$ \\
\hline \multirow{6}{*}{ Hengguan35 } & T0 & 331.3 & & & 2133.4 & \multirow{5}{*}{ Guan216 } & & & & 483.4 \\
\hline & $\mathrm{T} 1$ & 660.5 & 1179.9 & 5379.3 & 9133.8 & & 861.5 & 1284.2 & 5644.6 & 6878.1 \\
\hline & $\mathrm{T} 2$ & 637.3 & 1638.5 & 6771.8 & 10889.4 & & 774.3 & 971.1 & 6605.5 & 9639.4 \\
\hline & $\mathrm{T} 3$ & 463.0 & 1279.7 & 8249.8 & 11039.4 & & 431.8 & 1343.9 & 6352.0 & 9937.1 \\
\hline & $\mathrm{T} 4$ & 665.7 & 1621.0 & 7892.7 & 8839.3 & & 699.7 & 1100.6 & 7745.1 & 12984.0 \\
\hline & T0 & 344.4 & & & 388.9 & \multirow{5}{*}{ Shimail5 } & & & & 183.3 \\
\hline \multirow{4}{*}{ Shimai4185 } & $\mathrm{T} 1$ & 434.9 & 1419.1 & 5735.6 & 7400.4 & & 752.5 & 1554.5 & 5950.5 & 6194.8 \\
\hline & $\mathrm{T} 2$ & 201.4 & 1777.2 & 5600.3 & 9717.2 & & 683.1 & 1703.7 & 5952.9 & 9211.6 \\
\hline & $\mathrm{T} 3$ & 380.3 & 1344.3 & 6189.2 & 10215.3 & & 534.0 & 1361.9 & 6191.6 & 9716.7 \\
\hline & $\mathrm{T} 4$ & 375.3 & 1352.5 & 6362.7 & 10872.8 & & 595.5 & 1914.4 & 7350.4 & 10506.1 \\
\hline \multirow[t]{5}{*}{ Heng4399 } & T0 & & & & 500.0 & \multirow{5}{*}{ Jimai22 } & & & & 1411.2 \\
\hline & $\mathrm{T} 1$ & 450.9 & 1093.1 & 5603.4 & 6989.2 & & 590.1 & 1722.6 & 7110.4 & 8628.2 \\
\hline & $\mathrm{T} 2$ & 680.3 & 1089.4 & 6159.0 & 9144.9 & & 610.6 & 2177.9 & 7298.5 & 10239.4 \\
\hline & $\mathrm{T} 3$ & 649.2 & 982.5 & 7022.8 & 9174.9 & & 454.7 & 1590.9 & 7565.5 & 10300.8 \\
\hline & T4 & 603.5 & 1195.1 & 7575.6 & 9572.7 & & 613.2 & 1440.7 & 7630.6 & 11050.6 \\
\hline
\end{tabular}

\subsection{Wheat yield characteristics}

As seen from Table 4, the yield of different wheat varieties under different water treatments ranged from $70.5 \mathrm{~kg} / \mathrm{hm}{ }^{2}$ to $7053.0 \mathrm{~kg} / \mathrm{hm}^{2}$. Yield increased with the increase in irrigation times. The varieties with the lowest yields under T0, T1, T2, T3 and T4 were Shimai 15, Shimai 15, Shimai 4185, Shimai 15 and Heng 4399, and those with the highest yield were Jimai 22, Jimai 22, Guan35, Guan35 and Guan216, respectively.

Under different water treatment conditions, the 1000-grain weight of different varieties of wheat ranged from 33.36 g-46.48 g. The 1000-grain weight of Heng 4399 and Jimai 22 increased with the prolongation of irrigation times. The 1000 -grain weight of other varieties under T0 was low or the lowest. The 1000-grain weight increased differently with the increase in irrigation times. Amongst all varieties, Guan 216 had the lowest yield, and Jimai 22 had the highest or higher 1000-grain weight.

Table 4. Yield characteristics of each variety and treatment.

\begin{tabular}{|c|c|c|c|c|c|c|c|c|c|c|}
\hline \multirow[b]{2}{*}{ Variety } & \multirow[b]{2}{*}{$\begin{array}{l}\text { Treatm } \\
\text { ent }\end{array}$} & \multicolumn{4}{|l|}{ Yield factors } & \multirow[b]{2}{*}{ Variety } & \multicolumn{4}{|l|}{ Yield factors } \\
\hline & & $\begin{array}{l}\text { Panicle } \\
\text { number } \\
\left(\quad 10^{4} \cdot \text { spike }\right. \\
\left./ \mathrm{hm}^{2}\right)\end{array}$ & $\begin{array}{l}\text { Grain number } \\
\text { per spike } \\
\text { ( grain/spike } \\
\text { ) }\end{array}$ & $\begin{array}{l}1000 \text { seed } \\
\text { weight } \\
(\mathrm{g} / 1000 \text { grai } \\
\mathrm{n})\end{array}$ & $\begin{array}{l}\text { Yield } \\
\left(\mathrm{kg} / \mathrm{hm}^{2}\right)\end{array}$ & & $\begin{array}{l}\text { Panicle } \\
\text { number } \\
\left(\quad 10^{4} \cdot \text { spike }\right. \\
\left./ \mathrm{hm}^{2}\right)\end{array}$ & $\begin{array}{l}\text { Grain } \\
\text { number } \\
\text { per spike } \\
\text { ( grain/spi } \\
\text { ke ) }\end{array}$ & $\begin{array}{l}1000 \text { seed } \\
\text { weight } \\
(\mathrm{g} / 1000 \mathrm{gr} \\
\text { ain })\end{array}$ & $\begin{array}{l}\text { Yield } \\
\left(\mathrm{kg} / \mathrm{hm}^{2}\right)\end{array}$ \\
\hline \multirow{5}{*}{ Hengguan35 } & T0 & - & 27.63 & 35.80 & 1069.5 & \multirow{5}{*}{ Guan216 } & - & 23.01 & 33.64 & 186.0 \\
\hline & $\mathrm{T} 1$ & 434.91 & 38.41 & 41.87 & 4767.0 & & 497.61 & 31.44 & 33.36 & 3567.0 \\
\hline & $\mathrm{T} 2$ & 410.37 & 35.54 & 39.47 & 5347.5 & & 541.11 & 32.28 & 37.38 & 5103.0 \\
\hline & $\mathrm{T} 3$ & 445.93 & 37.05 & 41.04 & 6004.5 & & 506.81 & 34.75 & 37.09 & 5296.5 \\
\hline & $\mathrm{T} 4$ & 470.00 & 36.88 & 42.60 & 7053.0 & & 558.50 & 31.25 & 39.34 & 7048.5 \\
\hline \multirow{5}{*}{ Shimai4185 } & T0 & - & 22.14 & 38.30 & 169.5 & \multirow{5}{*}{ Shimai 15} & - & 19.95 & 35.80 & 70.5 \\
\hline & $\mathrm{T} 1$ & 508.15 & 31.81 & 36.27 & 3732.0 & & 455.74 & 37.18 & 39.16 & 3535.5 \\
\hline & $\mathrm{T} 2$ & 510.74 & 32.04 & 42.55 & 4309.5 & & 493.33 & 35.63 & 41.83 & 4827.0 \\
\hline & $\mathrm{T} 3$ & 487.41 & 32.24 & 40.67 & 5158.5 & & 509.04 & 32.85 & 40.92 & 5095.5 \\
\hline & $\mathrm{T} 4$ & 538.15 & 31.87 & 42.79 & 5682.0 & & 589.44 & 38.77 & 43.95 & 5829.0 \\
\hline Heng4399 & T0 & - & 23.51 & 36.97 & 169.5 & Jimai22 & - & 20.05 & 40.49 & 649.5 \\
\hline
\end{tabular}




\begin{tabular}{|c|c|c|c|c|c|c|c|c|}
\hline $\mathrm{T} 1$ & 462.96 & 33.68 & 37.49 & 3675.0 & 548.89 & 32.98 & 42.92 & 4567.5 \\
\hline $\mathrm{T} 2$ & 504.81 & 31.80 & 43.74 & 4812.0 & 567.69 & 31.57 & 44.13 & 4780.5 \\
\hline $\mathrm{T} 3$ & 494.44 & 34.79 & 43.81 & 5104.5 & 523.33 & 34.39 & 44.26 & 5553.0 \\
\hline $\mathrm{T} 4$ & 573.33 & 33.31 & 44.79 & 5265.0 & 606.89 & 31.17 & 46.48 & 5907.0 \\
\hline
\end{tabular}

\section{Discussion}

\subsection{Effects of irrigation mode on yield and water utilisation}

In this study, the extreme dry weather without effective precipitation lasted for 107 days from October 25 solstice after wheat sowing to February 8 of the following year [2]. Rainfall was only $47.7 \mathrm{~mm}$ during the wheat growth period, and its distribution was uneven. Wheat yield under different irrigation modes ranged from $70.5 \mathrm{~kg} / \mathrm{hm}^{2}$ to $7053.0 \mathrm{~kg} / \mathrm{hm}^{2}$. Yield gradually increased with the increase in irrigation times, and the yield of T4 was the highest. The effect of irrigation mode on panicle number was different from that on yield. The number of panicle formation under T0 was the lowest, and the difference under other treatments was small. The range of 1000-grain weight was 33.36-46.68 g. Except for that under T0 treatment, 1000-grain weight under other treatments increased with the increase in irrigation times. When the population difference was large, yield was related to the population size, and water regulation should be performed to increase the population. When the population difference was small, yield was related to 1000-grain weight, and water regulation should be carried out to increase the 1000-grain weight.

From the perspective of soil moisture changes, the deep soil moisture content under T0 and T4 was higher, whereas that under T1 and T2 was lower in the late growth stage. These results indicated that T1 and T2 contributed to the utilisation of water in deep soil and were efficient water use models. T1 and T2 were water saving irrigation models in this study.

\subsection{Relationship between irrigation mode and varieties and cultivation conditions}

The characteristics of crops, including water sensitivity, drought resistance and water-saving ability, differ amongst different varieties [6]. The yield of Hengguan 35 and Guan 216 under high-frequency irrigation treatment (T4) exceeded $7000 \mathrm{~kg} / \mathrm{hm}^{2}$, whereas that of other varieties under other treatments was less than $6000 \mathrm{~kg} / \mathrm{hm}^{2}$. This result indicated that Guan35 is a wheat variety with drought resistance and high and stable yield. Compared with the yields of different varieties under the same irrigation treatment, the yield of Guan 35 was the highest and had the smallest difference between treatments.

Under sufficient soil moisture, the yield under spring irrigation water (T1) was $3535.5-47,672 \mathrm{~kg} / \mathrm{hm}^{2}$ on April 15 , which was lower than that reported by Li et al $\left(6620.4-8650.5 \mathrm{~kg} / \mathrm{hm}^{2}\right)$ [4]. The panicle number of different wheat varieties under T1 treatment was $434.91 \times 10^{4}-548.89 \times 10^{4}$ plant $/ \mathrm{hm}^{2}$ and was lower than that reported by $\mathrm{Li}$ et al. $\left(522.5 \times 10^{4}-800.0 \times 10^{4} \mathrm{plant} / \mathrm{hm}^{2}\right)$. The main reason for the low population is related to the weak seedling condition caused by the deep sowing in this study. In actual production, the total stem number of the population should be controlled and kept within a reasonable range for water management. This approach can improve the root system's ability to absorb soil water [10] and ensure the stable increase of population yield to enable the synchronous improvement of yield and water use efficiency [11].

\section{Acknowledgments}

This project was supported by: The National Natural Science Funds Fund (51609245); Central Research Institutes of Basic Research and Public Service Special Operations (FIRI2017-07); Key Project of Chinese National Programs for Fundamental Research and Development ( 2018YFD0300505-3).

\section{References}

1. M.Z. Li, W.H. Zhang, Y.S. Zhang, H.K. Dhng, L. Wang, L.Q. HHe, K.J. Li, Y.M. Li, X. Du, Scientia Agricultura Sincia, 46(2013)

2. H.K. Dang, C.L. Zheng, J.Y. Ma, C.Y. Cao, G.F. Wang, W. Li, K.J. Li, Chinese Journal of Eco-Agriculture. 20(2012)

3. H.P. Li, Y.L. Zhang, L.J. Zhai, J.M. Li, X.Q. He, Journal of Shanxi Agricultural Sciences. 44(2016)

4. X.S. Li, H.K. Dang, N. Song, X.J. Shen, X.J. Ma, J.S. Sun, Transactions of the Chinese Society for Agricultural Machinery. 50(2019) 
5. H.G. Wang, Z.W. Yu, Y.L. Zhang, D. Wang, Acta Agronomica Sinica. 36(2010)

6. L.H. Lv, Y.K. Hu, Y.M. Li, P. Wang, Jorrnal of Triticeae Crops. 27(2007)

7. X.Y. Sun, K. Wu, Z.G. Qian, R.X. Wang, C. Wang, Y. Mi, Southwest China Journal of Agricultural Sciences. 24(2011)

8. L. Guan, K. Wang, P.F. Guo, H. Zhang, Journal of Anyang Institute of Technology. 9(2010)

9. C. Dong, R.J. Meng, D.P. He, M.L. Yan, Auhui Agricultural Science Bulletin. 18(2012)

10. X.Y. Zhang, X.L. Yuan, R.N. Han, H.X. Wang, Eco-Agriculture Research. 2(1994)

11. Z.M. Wang, P. Wang, X.H. Li, J.M. Li, L.Q. Lu, Review of China Agricultural Science and Technology. 8(2006) 